J. Environ. Sci.

Institute of Environmental Studies and Research - Ain Shams University

\title{
THE PRODUCTION OF TOMATO AND STRAWBERRY IN ECOLOGY URBAN AGRICULTURE
}

Shaaban, Kh. N. ${ }^{(1)}$; Mohamed, M. M. ${ }^{(1)}$ and El-Behairy, O. A. ${ }^{(2)}$

1) Central Laboratory for Agricultural Climate, Agricultural Research Centre, 2) Department of Horticulture, Ain, Shams University.

\begin{abstract}
ABSTARCT
The urban agriculture took more attention during the last two decades not just on global scale but also on local scale for many reasons such as food security and safety, climate change impacts and environmental concerns. The study was carried out on the roof of the Central Laboratory for Agriculture Climate (CLAC), Agriculture Research Centre, Egypt, during successive two summer seasons for tomato and two winter seasons for strawberry of (2014 2015). The study aimed to investigate the effect of different vermicompost rates mixed with standard substrate perlite (perlite: vermicompost $(90: 10)$ (Mix.10\%), perlite: vermicompost (80:20) (Mix.20\%), perlite: vermicompost (70:30) (Mix.30\%) and perlite (100V) (Control)) and nutrient solutions sources (chemical solution, vermi- liquid and chemical and vermi- liquid at constant EC for each crop under the study) on the yield and quality of tomato and strawberry under urban agriculture conditions. Physical and chemical properties of substrates, vegetative growth, quality characteristics, yield and $\mathrm{N}, \mathrm{P}$ and $\mathrm{K}$ of plant contents and heavy metals contents of fruits in both strawberry and tomato were determined.

The obtained results showed that the vegetative and yield characteristics, chemical quality properties, $\mathrm{N}, \mathrm{P}$ and $\mathrm{K}$ leaves contents and heavy metals contents of tomato and strawberry fruits were affected strongly by vermicompost rate mixed with substrate. The highest vegetative growth and yield characteristics and $\mathrm{N}, \mathrm{P}$ and $\mathrm{K}$ contents of tomato and strawberry were given by chemical followed by vermi-chemical nutrient solution combined with Mix.30\% followed by Mix.20\%. Vermicompost either its application or increasing rate had a positive impact on reducing the heavy metals contents of tomato and strawberry fruits. The use of vermi-liquid as a nutrient solution and vermicompost as a substrate amendment had a positive impact not just on
\end{abstract}


tomato and strawberry production (food security) via urban agriculture but also on environmental issue and climate change adaptation.

Keywords: Green roofs, urban agriculture, vermicomposting, vermicompost, nutrient solution, Substrate culture, Tomato, Strawberry.

\section{INTRODUCTION}

Under climate change impacts and food security needs, urban horticulture should play a vital role in producing the food via using green roof systems and at the same time securing the recycle of urban organic wastes for mitigate $\mathrm{CO}_{2}$ emission and save the essential nutrients. Urban horticulture includes all horticultural crops grown for human consumption and ornamental use. Urban horticulture is not just working on producing large variety of vegetables, cereals, flowers, ornamental trees, aromatic vegetables and mushrooms but also fight the climate change impacts, poverty, hungry, malnutrition and illness while help food security, economy and social needs (FAO 2012).

Many researchers in different countries have investigated the urban agriculture mainly in soil cultivation on different scales and viewpoints such as: contamination effect of trace and heavy elements in urban soils on leafy vegetables growth and production ( Nabulo et al., 2010, Saumel et al., 2012 and McBride et al., 2014), human health risk assessment of vegetables consumed from contaminated urban soil and foodborne pathogens ( Saumel et al., 2012, Lagerkvist et al., 2013, Nicklett and Kadall 2013 and Swartjes et al., 2013), The role of urban agriculture in sustainable production and food security in urban and peri-urban areas ( Hara et al., 2013, Rego 2014, Wertheim-Heck et al., 2014 and Bvenura and Afolayan 2015) and the 
importance of leafy vegetables on human health in poor urban and peri-urban ( Uusiku et al., 2010, Nicklett and Kadall 2013, Wertheim-Heck et al., 2014 and Bvenura and Afolayan 2015).

Abul-Soud (2015) mentioned that under Egyptian condition, urban agriculture mainly had a strong exist via using modified soilless culture systems on roofs (green roof) regarding to the high urbanization and agriculture soil shortage. The use of soilless culture techniques in producing vegetables under urban agricultural led to avoid the problems of urban soil contamination, shortage of soil, water and natural resources beside maximizing the production. The real advantages of using soilless culture in urban agriculture are the using of neglect able area as rooftop as cultivation area and the high water use efficiency. Alternating peat moss substrate by local substrate such as vermicompost contribute in reducing the cost and increase the sustainability of the urban agriculture systems (substrate culture).

The use of earthworms in converting and decomposing (vermicomposting) the organic urban wastes into high enrich organic fertilizer (vermicompost) had many objectives not just on environmental scale but also on climate change, economic, public health, social, public awareness and food production scales. Compared to their parent materials, vermicompost have less soluble salts, greater cation exchange capacity, and increased total humic acid contents (Atiyeh et al., 2002, Abul-Soud et al., 2009, Abul-Soud et al., 2014 and Abul-Soud et al., 2015). The application of vermicomposting outputs (vermicompost and vermi-liquid) in soil, under greenhouse, soilless culture and green roof system have beneficial impacts on different crops such as cucumber, sweet paper (Abul-Soud et al., 2012). 
The aims of this study were determining the ability of vermicomposting in recycling urban organic wastes and use its output as an organic substrate to enhance the physical and chemical properties of substrate in pot culture and its effect on tomato and strawberry growth and yield.

\section{MATERIALS AND METHODS}

The study was carried out on the roof of the Central Laboratory for Agriculture Climate (CLAC), Agriculture Research Centre, Egypt, during successive two summer seasons for tomato and two winter seasons for strawberry of (2014 - 2015).

Plant materials: Strawberry (Fragaria xananassa), cv, Festival F1 hybrid was used in this study. Fresh transplants were planted on 15th September in both growing autumn seasons (2013 and 2014) in pots. One plant was planted in each pot.

Tomato ( Remas F1 ) seeds were sown in the first of June of 2014 and 2015 and both growing summer seasons, respectively, in polystyrene trays. After the fourth true leaf stage (6 weeks), the transplants were planted in plastic pots. One plant was planted in each pot.

The vermicomposting process: The Epigiec earthworms Lumbriscus Rubellus (Red Worm), Eisenia Fetida (Tiger Worm), Perionyx Excavatus (Indian Blue) and Eudrilus Eugeniae (African Night Crawler) were used in plastic container as an indoor system of vermicomposting. Holed plastic container $(40 \times 40 \times 60 \mathrm{~cm})$ were established as indoor system of vermicomposting. Each holed plastic box had $250 \mathrm{~g}$ of epigiec earthworms to begin the study. Worm diameter: $0.5-5 \mathrm{~mm}$ and worm length: $10-120 \mathrm{~mm}$. 
The vermicomposting process and vermicompost and vermi-liquid production were done according to Abul-Soud et al., 2009, 2014, 2015 (a and b). Kitchen wastes (vegetables and fruit scraps + food wastes) + newspaper in proportions (80: $20 \%$ ) were vermicomposting as an urban organic wastes.

Table (1): The chemical composition (\%) of the different agricultural wastes.

\begin{tabular}{|c|c|c|c|c|c|c|}
\hline \multirow{2}{*}{ Raw material } & \multirow{2}{*}{ C/N ratio } & \multicolumn{5}{|c|}{ macro elements \% } \\
\cline { 3 - 7 } & & $\mathbf{N}$ & $\mathbf{P}$ & $\mathbf{K}$ & $\mathbf{C a}$ & $\mathbf{M g}$ \\
\hline \hline kitchen wastes & 50.23 & 0.59 & 0.44 & 0.56 & 0.98 & 0.62 \\
\hline Sh.P & 169.01 & 0.017 & 0.01 & 0.00 & 0.19 & 0.01 \\
\hline the mix & 76.5 & 0.54 & 0.38 & 0.49 & 0.73 & 0.55 \\
\hline
\end{tabular}

Experiential set up: Growing plastic black pots were filled with 8 liters of the substrate mixtures regarding to the different treatments. The pots were arranged in 3 rows for tomato and 4 rows for strawberry over aluminum tables ( $1 \times 2 \times 0.6 \mathrm{~m})$; every table was contained 24 pots for tomato and 32 plants for strawberry per table $(2 \mathrm{~m} 3)$.

Nutrient solution (El-Behairy, 1994) and the fresh harvested vermi-liquid from vermicomposting system were used for both strawberry and tomato and both seasons in this experiment. The EC of the different nutrient solutions were adjusted by using EC meter to the required level for each crop ( $2 \mathrm{ds} \mathrm{m}-1$ for strawberry and up to $3 \mathrm{ds} \mathrm{m}-1$ for tomato).

Table (2): The chemical composition of different sources of nutrient solutions

\begin{tabular}{|c|c|c|c|c|c|c|c|c|c|c|c|c|}
\hline \multirow{2}{*}{ Nutrient source } & \multicolumn{5}{|c|}{ Macronutrients } & \multicolumn{5}{|c|}{ Micronutrients } & \multicolumn{2}{|c|}{ Heavy metals } \\
\hline & $\mathbf{N}$ & $\mathbf{P}$ & $\mathbf{K}$ & $\mathbf{C a}$ & Mg & $\mathbf{F e}$ & Mn & Zn & B & $\mathrm{Cu}$ & $\mathbf{P b}$ & Cd \\
\hline Vermi-liquid & 132 & 92 & 191 & 87 & 56 & 8.72 & 1.91 & 0.29 & 0.28 & 0.15 & n.d & n.d \\
\hline Chemical & 210 & 45 & 300 & 150 & 60 & 6 & 0.8 & 0.4 & 0.25 & 0.12 & 0.1 & 0.01 \\
\hline
\end{tabular}

n.d = not detected 
The investigated treatments: Two factors were investigated under the study. First, four different substrate mixtures perlite:vermicompost $(90: 10 \mathrm{~V} / \mathrm{V})$ (Mix.10\%), perlite: vermicompost (80 :20 V/V) (Mix.20\%), perlite: vermicompost (70:30) (Mix.30\%) and perlite (100V) (Control combined with three nutrient solution sources treatments \{(chemical solution, vermiliquid and chemical and vermi- liquid) (50:50\% on base of ds $\mathrm{m}-1$ ) $\}$ as a second factor. The EC of different nutrient solution source were adjusted regarding to each standard EC level for each crop (Strawberry and Tomato).

The experimental design was split blocks with 3 replicates.

\section{The measurements:}

The vegetative and yield characteristics: at the end of growing seasons of tomato. Plant height $(\mathrm{cm})$, number of leaves diameter of stem, number of fruits, weight of fruits, total yield, yield /plant, yield $/ \mathrm{m} 2$, leave area. At the end of growing seasons of strawberry. Number of leaves, number of fruits, total yield, leaves area

Chemical characteristics: Ascorbic acid (vitamin C): was determined in mg/ $100 \mathrm{~g}$ fresh weight by using the 2, 6 Di-chlorophenol method (A.O.A.C., 1990). Total soluble solids (TSS): The percentage of TSS was determined by using hand refractometer (A.O.A.C., 1990).

Total nitrogen was determined by Kjeldahl method according to the procedure described by (FAO 1980). Phosphorus content was determined using spectrophotometer according to Watanabe and Olsen (1965). Potassium content was determined photometrically using Flame photometer as described by Chapman and Pratt (1961). Heavy metals contents 
$(\mathrm{Pb}, \mathrm{Cd}, \mathrm{Ni}, \mathrm{Co})$ of fruits were estimated according to Phillips Unicum Atomic Absorption spectrophotometer as described by Chapman and Pratt (1961).

\section{The physical and chemical properties of different substrates mixtures were estimated according to Wilson (1983) and Raul (1996) as follows:-}

The bulk density (B.D) is simply measured as dry weight/volume $(\mathrm{g} / \mathrm{cm} 3$ or $\mathrm{kg} / \mathrm{l})$.

Total pore space (T.P.S) is the percentage pore space and the proportion and amount of water and air that is present in pore space

Total pore space $=(1-$ bulk density/ true density $) \times 100$

Water hold capacity \% (W.H.C) is the amount of water present after the substrate in a container has been saturated and allowed to drain.Water hold capacity $\%=((\mathrm{FW}-\mathrm{DW}) / \mathrm{VB}) \times 100$

FW (fresh weight $)=$ weight of substrate after stop draining

DW ( dry weight $)=$ dry weight of substrate after 24 hours at a temperature $80-90 \mathrm{oC}$. Air porosity \% (A.P) is the proportion of the volume of substrate (VB) that contains air after it has been saturated with water and allowed to drain. Collect the volume of water leached plus the volume of air present after the substrate in a container allowed to drain.

Air porosity $\%=$ T.P.S - W.H.C.The $\mathrm{pHs}$ of the potting mixtures were determined using a double distilled water suspension of each potting mixture in the ratio of 1:10 (w: v) (Inbar et al., 1993) that had been agitated mechanically for $2 \mathrm{~h}$ and filtered through Whatman no.1 fillter paper. The same solution was measured for electrical conductivity with a conductance meter that had been standardized with 0.01 and $0.1 \mathrm{M} \mathrm{KCl}$. 
Table (3): The physical and chemical properties of different substrates mix of study.

\begin{tabular}{|c|c|c|c|c|c|c|c|}
\hline & \multicolumn{4}{|c|}{ Physical } & \multicolumn{3}{|c|}{ chemical } \\
\hline Substrate & $\begin{array}{c}\text { B.D. } \\
(\mathbf{k g} / \mathbf{I})\end{array}$ & $\begin{array}{c}\text { T.P.S. } \\
(\boldsymbol{\%})\end{array}$ & $\begin{array}{c}\text { W.H.C. } \\
(\boldsymbol{\%})\end{array}$ & $\begin{array}{c}\text { A.P. } \\
(\boldsymbol{\%})\end{array}$ & $\begin{array}{c}\text { E.C. } \\
(\mathbf{d s m}-\mathbf{1})\end{array}$ & $\mathbf{p H}$ & $\begin{array}{c}\text { O.M. } \\
(\boldsymbol{\%})\end{array}$ \\
\hline Control & 0.125 & 90 & 30.5 & 59.5 & 0.34 & 7.4 & 0 \\
\hline Mix. 10\% & 0.239 & 85.7 & 36.8 & 48.9 & 0.76 & 7.6 & 7.951 \\
\hline Mix. 20\% & 0.341 & 78.6 & 43.3 & 35.3 & 1.05 & 7.8 & 11.145 \\
\hline Mix. 30\% & 0.43 & 74.5 & 48.5 & 26 & 1.21 & 7.9 & 13.257 \\
\hline
\end{tabular}

B.D bulk density . T.P.S total pore space .W.H.C water hold capacity. A.P air porosity.

The statistical analysis: Statistical analysis was determined by computer, using SAS program for statistical analysis. The differences among means for all traits were tested for significance at $5 \%$ level according to the procedure described by Snedicor and Cochran (1981).

\section{RESULTS}

\section{Tomato: The effect of nutrient solution source and vermicompost rate} on:

1. Vegetative growth and yield characteristics: The effect of using different nutrient solution sources had no significant effect on vegetative and yield characteristics as presented in Table (4).

On the other hand, the obtained data (Table 4) indicated that increasing of vermicompost rate mixed with substrate from 10 to $30 \%$ led to significantly increase regardly the vegetative and yield characteristics compared to control treatment. The highest results of stem diameter, number of leaves, number of fruits/plant and total yield of tomato were obtained by 
J. Environ. Sci.

Institute of Environmental Studies and Research - Ain Shams University

the vermicompost rate $30 \%$ while the lowest values recorded by control treatment.

Regarding to the interaction impact between different nutrient solution sources and vermicompost rates, the reveled data showed that the use of mix $30 \%$ combined with chemical nutrient solution recorded the highest value of stem diameter, number of leaves number of fruits/plant and total yield of tomato. The lowest records of vegetative and yield characteristics were observed by control substrate treatment combined with vermi-liquid as a nutrient solution.

2. Chemical quality properties: Table (5) presented the effect of different nutrient solution sources and vermicompost rates on chemical characteristics of tomato. The treatment of vermi-chemical nutrient solution presented the highest value of TSS, while there were no significant difference among the different nutrient solution sources on total chlorophyll content and Vit. C. The vermi-liquid treatment gave the lowest TSS.

The highest values of total chlorophyll content, TSS and Vit.C. recorded by vermicompost rate mix $30 \%$ while control had the lowest results. The vermicompost had a positive effect on the chemical characteristics of tomato compared to the control.

The interaction among the different treatments as presented in table (5) showed that chemical nutrient solution combined with mix $30 \%$ treatment had the highest significant records of TSS but non-significantly with total chlorophyll content, and Vit. C. while the lowest results of chemical 
characteristics of tomato fruit were presented by vermi-liquid nutrient solution combined with control substrate treatment

3. Macro elements: The use of chemical nutrient solution gave the highest significant N, P and K\% of tomato leaves (Table 6).

Also, increasing the vermicompost rate up to $30 \%$ led to increase significantly $\mathrm{N}, \mathrm{P}$ and $\mathrm{K} \%$ of tomato leaves. The Mix $30 \%$ treatment observed the highest values of $\mathrm{N}, \mathrm{P}$ and $\mathrm{K}$ contents of tomato leaves while the lowest results of $\mathrm{N}, \mathrm{P}$ and $\mathrm{K} \%$ recorded by control treatment.

Table (6) presented the interaction effect among the different treatments, the obtained data showed that the use of chemical nutrient solution combined with mix $30 \%$ recorded the highest values of $\mathrm{N}, \mathrm{P}$ and $\mathrm{K} \%$ of tomato leaves.

4. Heavy metals in the fruits: Table (7) presented that all values of $\mathrm{Pb}$ and $\mathrm{Cd}$ concentration in tomato fruits were not detected. The treatment of chemical nutrient solution present the highest value of $\mathrm{Ni}$ and $\mathrm{Co}$ while the lowest values recorded by vermi-liquid. On the other hand the highest record of $\mathrm{Ni}$ and $\mathrm{Co}$ gave by mix $30 \%$ while the control had the lowest results.

The interaction among the difference treatment showed that chemical nutrition solution combined with control substrate treatment had the highest records of $\mathrm{Ni}$ and $\mathrm{Co}$. While the lowest result of $\mathrm{Ni}$ and $\mathrm{Co}$ recorded by vermi-liquid and vermi-chemical combined with mix $30 \%$ treatment.

2. Strawberry: The effect of nutrient solution source and vermicompost rate on:

1. Vegetative growth and yield characteristics: Table (8) presented the effect of different sources of nutrient solution and substrate mixtures on vegetative and yield characteristics of strawberry. Similar trends and 
approaches were obtained as well as tomato results. The effect of using different solution source had no significant effect on vegetative growth and yield characteristics

Regarding to the effect of vermicompost rate on No. of leaves, Average leaf area and total yield/ plant of strawberry, Mix $30 \%$ treatments recorded the highest significant increase of vegetative growth compared with control .

On the other hand, the interaction impact between different nutrient solution sources and substrates mixes showed that the use of chemical nutrient solution combined with mix $30 \%$ presented the highest results of number of leaves, number of fruits / plant and total yield of strawberry. The lowest significant values of vegetative and yield characteristics were recorded by vermi-liquid nutrient solution combined with control substrate treatment as Table (8) presented.

2. Chemical quality properties: The treatment of vermi-chemical nutrient solution presented the highest values of vitamin C, TSS, and total chlorophyll content .On the other hand, the highest value of acidity was presented by chemical nutrient solution (Table 9).

The obtained results of Table (9) indicated that the highest results of Vit. C, TSS, acidity and total chlorophyll content gave by mix $30 \%$ while control had the lowest results. Increasing the vermicompost rate and its application had a positive effect on the chemical quality properties of strawberry compared to the control.

The interaction among the different treatments as presented in Table (9) showed that vermi-chemical nutrition solution combined with mix $30 \%$ had the highest records of TSS and vitamin C. While using chemical nutrition 
solution combined with mix $30 \%$ recorded the highest results of by acidity and total chlorophyll content. Moreover, the lowest chemical quality properties were observed using vermi-liquid combined with control treatment.

3. Macro elements: Table (10) presented similar trends and approaches were obtained as well as tomato results. The application of chemical nutrient solution and vermicompost rate $30 \%$ performed the highest $\mathrm{N}, \mathrm{P}$ and $\mathrm{K} \%$ of strawberry leaves.

Otherwise, vermi-liquid and control substrate presented the lowest values of $\mathrm{N}, \mathrm{P}$ and $\mathrm{K} \%$ of strawberry leaves.

Regarding to the interaction impact between different substrates mixes and nutrient solution sources, the reveled data showed that the use of mix $30 \%$ combined with chemical nutrient solution recorded the highest values of $\mathrm{N}, \mathrm{P}$ and $\mathrm{K} \%$ of strawberry leaves as .

4. Heavy metals in the fruits: Table (11) presented that all values of $\mathrm{Pb}$ concentration in strawberry fruits regarding to the different treatments of nutrient solution sources and vermicompost rates were not detected. The treatment of chemical nutrient solution present the highest strawberry fruit contents of $\mathrm{Ni}, \mathrm{Cd}$ and $\mathrm{Co}$ while the lowest values recorded by vermiliquid. On the other hand the highest record of $\mathrm{Cd}, \mathrm{Ni}$ and $\mathrm{Co}$ gave by mix $30 \%$ while the control had the lowest results, moreover, the interaction among the difference treatment showed that chemical nutrition solution combined with control had the highest records of $\mathrm{Cd}, \mathrm{Ni}$ and $\mathrm{Co}$ concentration in the fruits. While the lowest result of $\mathrm{Cd}, \mathrm{Ni}$ and $\mathrm{Co}$ recorded by vermi-liquid nutrient solution combined with mix $30 \%$ treatment as Table (11) presented. 
J. Environ. Sci.

Institute of Environmental Studies and Research - Ain Shams University

\section{DISCUSSION}

From the overall results, data showed that using vermicompost rate mixed with substrate had a positive impact on vegetative growth and yield characteristics. There are only few research studies that have examined the responses of plants to the use or substitution of vermicompost to soil or greenhouse container media (Wilson and Carlile 1989; Buckerfield and Webster 1998). Atiyah et al., 2002 and Chamani et al., 2008 demonstrated that vermicomposts have considerable potential for improving plant growth significantly, when used as components of horticultural soil or container media using different plant species. upon the source of the parent waste material used in their production. Vermicompost applications increased strawberry plant growth and yield significantly (Aracnon et al., 2004b).

The results of chemical quality properties affected by different vermicompost rates mixtures. Photosynthetic pigments and a significant increase in the ratio of chlorophyll relative to the control in an experiment involving beans it was observed that addition of $8.2 \% \mathrm{w} / \mathrm{w}$ vermicompost /soil induced the largest increase in chlorophyll content in the leaves of common bean (Phaseolus vulgaris.L) plants (Fernández-Luqueño et al., 2010) .

The use of vermi-liquid as a nutrient solution and vermicompost as a substrate amendment had a positive impact on tomato and strawberry production. Concerning, the combined between chemical nutrient solution with perlite mixtures were gave highest values in $\mathrm{N}$ and $\mathrm{P}$ content with vermicompost rate $(90+10 \mathrm{v} / \mathrm{v})$ has been observed by Datt et al., 2013 and Sharma et al., 2008 respectively. 
$\mathrm{N}, \mathrm{P}$ and $\mathrm{K}$ leaves contents and heavy metals contents of tomato and strawberry fruits were affected strongly by vermicompost rate mixed with substrate.These results coincided with that recommended on vermicompost application for encouraging plant growth and quality through increase the available forms of nutrients (nitrates, exchangeable $\mathrm{P}, \mathrm{K}, \mathrm{Ca}$ and $\mathrm{Mg}$ ) for plant uptake of strawberry (Arancon et al., 2004b).Vermicomposts are comprised of large amounts of humic substances which release nutrients relatively slowly in the soil that improve its physical and biological properties of soil and in turn rise to much better plant quality(Muscolo et al., 1999). Vermicompost play a vital role in decreasing the heavy metals by chelated them and prevent their uptake by plants. These results recommend the use of vermicompost mixed with substrate as soil amendment to reduce the $\mathrm{Pb}$ contamination.

Table 4: The effect of different sources of nutrient solution and Vermicompost rate on vegeatative and vield tharacteristics of tomato.

\begin{tabular}{|c|c|c|c|c|c|c|c|c|c|c|}
\hline \multirow[t]{2}{*}{ Treatments } & \multicolumn{5}{|c|}{ First season 2014} & \multicolumn{5}{|c|}{ Second season 2015} \\
\hline & \multicolumn{5}{|c|}{ Vermicompost rate } & \multicolumn{5}{|c|}{ Vermicompose rate } \\
\hline Nutrient solution & Control & Mix 10\% & $\operatorname{Mix} 20 \%$ & $\operatorname{Mix} 30 \%$ & Mean(B) & Control & $\operatorname{Mix} 10 \%$ & Mix 20\% & Mix 30\% & Mean(B) \\
\hline \multicolumn{11}{|c|}{ Stem diameter (mm) } \\
\hline Chemical & $8.16 b c$ & $8.66 a b c$ & $8.50 \mathrm{abc}$ & $10.16 \mathrm{a}$ & $8.87 \mathrm{~A}$ & $8.64 b c$ & $9.17 a b c$ & $9.01 \mathrm{abc}$ & $10.77 \mathrm{a}$ & $9.40 \mathrm{~A}$ \\
\hline Vermi-liquid & $7.75 \mathrm{c}$ & $9.00 a b c$ & $8.66 a b c$ & $9.91 \mathrm{ab}$ & $8.83 \mathrm{~A}$ & $8.21 \mathrm{C}$ & $9.54 a b c$ & $9.18 \mathrm{abc}$ & $10.50 \mathrm{ab}$ & $9.35 \mathrm{~A}$ \\
\hline Vermi-chemical & $8.00 \mathrm{C}$ & $8.25 b c$ & $8.66 \mathrm{abc}$ & $9.41 \mathrm{ab}$ & $8.58 \mathrm{~A}$ & $8.48 \mathrm{c}$ & $8.75 b c$ & $9.17 \mathrm{abc}$ & $9.97 \mathrm{ab}$ & $9.09 \mathrm{~A}$ \\
\hline $\operatorname{Mean}(A)$ & 7.978 & $8.63 \mathrm{~B}$ & $8.61 \mathrm{~B}$ & $9.83 \mathrm{~A}$ & & $8.44 B$ & $9.14 \mathrm{~B}$ & $9.12 B$ & $10.41 \mathrm{~A}$ & \\
\hline \multicolumn{11}{|c|}{ Number of leaves } \\
\hline Chemical & 33.160 & $38.75 \mathrm{~cd}$ & $47.58 \mathrm{abc}$ & $59.00 \mathrm{a}$ & $44.62 \mathrm{~A}$ & $35.14 d$ & $41.07 \mathrm{~cd}$ & $50.43 a b c$ & $62.54 a$ & $47.29 \mathrm{~A}$ \\
\hline Vermi-liquid & $32.33 d$ & $36.25 \mathrm{~cd}$ & $44.90 \mathrm{bcd}$ & $53.16 a b$ & $41.66 \mathrm{~A}$ & $34.26 \mathrm{~d}$ & $38.43 \mathrm{~cd}$ & $47.59 \mathrm{bcd}$ & $56.35 \mathrm{ab}$ & $44.15 \mathrm{~A}$ \\
\hline Vermi-chemical & $33.16 d$ & $39.58 \mathrm{~cd}$ & $47.58 \mathrm{abc}$ & $55.16 \mathrm{ab}$ & $43.87 \mathrm{~A}$ & $35.14 d$ & $41.95 \mathrm{~cd}$ & $50.43 a b c$ & $58.46 \mathrm{ab}$ & $46.49 \mathrm{~A}$ \\
\hline $\operatorname{Mean}(A)$ & 32.890 & $38.19 \mathrm{C}$ & 46.698 & $55.78 \mathrm{~A}$ & & 34.860 & $40.48 \mathrm{C}$ & 49.498 & $59.12 \mathrm{~A}$ & \\
\hline \multicolumn{11}{|c|}{ Number of fruits / plant } \\
\hline Chemical & $10.02 \mathrm{C}$ & $10.69 \mathrm{C}$ & $11.22 \mathrm{~b}$ & $18.16 \mathrm{a}$ & $12.52 \mathrm{~A}$ & $10.62 \mathrm{C}$ & $11.33 \mathrm{C}$ & $11.89 b$ & $19.24 \mathrm{a}$ & $13.27 \mathrm{~A}$ \\
\hline Vermi-liquid & $7.32 \mathrm{c}$ & $7.87 \mathrm{c}$ & $8.39 b c$ & $15.53 \mathrm{~b}$ & $9.78 \mathrm{~A}$ & $7.75 \mathrm{c}$ & $8.34 c$ & $8.89 b c$ & $16.46 \mathrm{~b}$ & $10.36 \mathrm{~A}$ \\
\hline Vermi-chemical & $8.19 \mathrm{c}$ & $9.36 b$ & $11.17 b$ & $16.48 \mathrm{a}$ & $11.30 \mathrm{~A}$ & $8.88 \mathrm{C}$ & $9.95 b$ & $11.84 b$ & $17.46 \mathrm{a}$ & $11.97 \mathrm{~A}$ \\
\hline $\operatorname{Mean}(A)$ & $8.51 b$ & $9.31 b$ & $10.26 b$ & $16.72 \mathrm{~A}$ & & $9.02 B$ & $9.86 \mathrm{~B}$ & $10.87 \mathrm{~B}$ & $17.72 \mathrm{~A}$ & \\
\hline \multicolumn{11}{|c|}{ Total yiald (g/plant) } \\
\hline Chemical & $1342.27 \mathrm{~d}$ & $1530.27 \mathrm{C}$ & $1632.51 b$ & $2602.14 a$ & $1776.96 \mathrm{~A}$ & $1422.80 \mathrm{~d}$ & $1622.08 \mathrm{C}$ & $1730.46 b$ & $2758.26 a$ & $1883.57 \mathrm{~A}$ \\
\hline Vermi-liquid & $825.98 d$ & $955.49 \mathrm{C}$ & $1037.33 \mathrm{C}$ & $1917.48 a$ & $1183.08 \mathrm{~A}$ & $875.53 \mathrm{~d}$ & $1012.81 \mathrm{c}$ & $1099.57 \mathrm{C}$ & $2032.52 a$ & $1254.06 \mathrm{~A}$ \\
\hline Vermi-chemical & $1007.86 \mathrm{~d}$ & $1218.85 \mathrm{C}$ & $1487.62 \mathrm{~b}$ & $2200.24 a$ & $1478.83 \mathrm{~A}$ & $1068.33 \mathrm{~d}$ & $1291.98 \mathrm{C}$ & $1576.87 \mathrm{~b}$ & $2332.25 a$ & $1567.56 \mathrm{~A}$ \\
\hline $\operatorname{Mean}(A)$ & $1049.19 \mathrm{C}$ & $1225.19 \mathrm{BC}$ & $1375.85 B$ & $2198.43 \mathrm{~A}$ & & $1112.14 \mathrm{C}$ & $1298.70 \mathrm{BC}$ & $1458.41 \mathrm{~B}$ & $2364.26 \mathrm{~A}$ & \\
\hline
\end{tabular}


J. Environ. Sci.

Institute of Environmental Studies and Research - Ain Shams University

Table 5: The effect of different sources of nutrient solution and Vermicompost rate on chemical characteristics of tomato.

\begin{tabular}{|c|c|c|c|c|c|c|c|c|c|c|}
\hline \multirow[t]{2}{*}{ Treatments } & \multicolumn{5}{|c|}{ First season 2014} & \multicolumn{5}{|c|}{ Second season 2015} \\
\hline & \multicolumn{5}{|c|}{ Vermicompost rate } & \multicolumn{5}{|c|}{ Vermicompost rate } \\
\hline Nutrient solution & control & $\operatorname{Mix} 10 \%$ & Mix 20\% & Mix $30 \%$ & Mean(B) & Control & $\operatorname{Mix} 10 \%$ & $\operatorname{Mix} 20 \%$ & Mix $30 \%$ & Mean(B) \\
\hline \multicolumn{11}{|c|}{ Total chlorophyll content (Spad) } \\
\hline Chemical & $48.22 \mathrm{C}$ & $51.89 b$ & $53.67 a b$ & $55.64 \mathrm{a}$ & $52.35 \mathrm{~A}$ & $51.11 \mathrm{c}$ & $55.00 \mathrm{~b}$ & $56.89 \mathrm{ab}$ & 58.97 a & $55.49 \mathrm{~A}$ \\
\hline Vermi-liquid & $47.46 \mathrm{c}$ & $50.33 b$ & $53.23 a b$ & $56.56 \mathrm{a}$ & $51.89 \mathrm{~A}$ & $50.30 \mathrm{C}$ & $53.34 b$ & $56.42 a b$ & $59.95 \mathrm{a}$ & $55.00 \mathrm{~A}$ \\
\hline Vermi-chemical & $48.11 \mathrm{c}$ & $49.60 \mathrm{~b}$ & $52.77 \mathrm{~b}$ & $57.38 \mathrm{a}$ & $51.96 \mathrm{~A}$ & $50.99 \mathrm{C}$ & $52.57 \mathrm{bc}$ & $55.93 b$ & $60.82 \mathrm{a}$ & $55.07 \mathrm{~A}$ \\
\hline $\operatorname{Mean}(A)$ & $47.93 \mathrm{C}$ & $50.61 \mathrm{BC}$ & $53.23 \mathrm{~B}$ & $56.53 \mathrm{~A}$ & & $50.80 \mathrm{C}$ & $53.64 \mathrm{BC}$ & 56.428 & $59.92 \mathrm{~A}$ & \\
\hline \multicolumn{11}{|c|}{ T.S.S (\%) } \\
\hline Chernical & $6.60 \mathrm{c}$ & $8.16 b c$ & $8.38 \mathrm{bc}$ & $10.38 \mathrm{ab}$ & $8.38 \mathrm{AB}$ & $7.00 \mathrm{C}$ & $8.64 b c$ & 8.88 bc & $11.00 \mathrm{ab}$ & $8.88 \mathrm{AB}$ \\
\hline Vermi-liquid & $6.90 \mathrm{c}$ & $7.83 b c$ & $6.80 \mathrm{C}$ & $9.20 b c$ & 7.688 & $7.31 \mathrm{C}$ & $8.29 b c$ & $7.20 \mathrm{c}$ & $9.75 b c$ & $8.14 \mathrm{~B}$ \\
\hline Vermi-chemical & $7.10 \mathrm{c}$ & $7.86 b c$ & $10.03 \mathrm{ab}$ & $12.26 \mathrm{a}$ & $9.31 \mathrm{~A}$ & $7.53 \mathrm{C}$ & $8.33 b c$ & $10.63 a b$ & $12.99 \mathrm{a}$ & $9.89 \mathrm{~A}$ \\
\hline $\operatorname{Mean}(A)$ & $6.87 \mathrm{C}$ & $7.95 \mathrm{~B}$ & $8.40 \mathrm{~B}$ & $10.62 \mathrm{~A}$ & & $7.28 \mathrm{C}$ & $8.42 \mathrm{~B}$ & $8.90 \mathrm{~B}$ & $11.25 \mathrm{~A}$ & \\
\hline \multicolumn{11}{|c|}{ Vitamin C (mg/100gf:w) } \\
\hline Chemical & $391.08 \mathrm{C}$ & $439.29 \mathrm{C}$ & $518.03 \mathrm{~b}$ & $614.46 \mathrm{a}$ & $490.71 \mathrm{~A}$ & $414.54 \mathrm{c}$ & $465.64 \mathrm{C}$ & $549.11 b$ & $651.32 \mathrm{a}$ & $520.15 \mathrm{~A}$ \\
\hline Vermi-liquid & $307.03 \mathrm{~d}$ & $349.06 \mathrm{~cd}$ & $453.80 \mathrm{bc}$ & $551.53 \mathrm{ab}$ & $415.35 \mathrm{~A}$ & $325.45 \mathrm{~d}$ & $370.00 \mathrm{~cd}$ & $481.02 b c$ & $584.62 \mathrm{ab}$ & $440.27 \mathrm{~A}$ \\
\hline Vermi-chemical & $364.34 \mathrm{~cd}$ & $370.98 \mathrm{~cd}$ & $507.99 \mathrm{~b}$ & $608.13 \mathrm{a}$ & $462.86 \mathrm{~A}$ & $386.20 \mathrm{~cd}$ & $393.23 \mathrm{~cd}$ & $538.46 \mathrm{~b}$ & $644.61 \mathrm{a}$ & $490.62 \mathrm{~A}$ \\
\hline $\operatorname{Mean}(A)$ & $349.06 \mathrm{D}$ & $391.54 \mathrm{C}$ & $493.27 \mathrm{~B}$ & $591.37 \mathrm{~A}$ & & $370.00 \mathrm{D}$ & $415.03 \mathrm{C}$ & $522.87 \mathrm{~B}$ & $626.86 \mathrm{~A}$ & \\
\hline
\end{tabular}

Table 5: The offect of different sources of nurrient solution and Vermicompost rate on macro elements \% of tomato leaves.

\begin{tabular}{|c|c|c|c|c|c|c|c|c|c|c|}
\hline \multirow{3}{*}{ Treatments } & \multicolumn{5}{|c|}{ First season 2014} & \multicolumn{5}{|c|}{ Second season 2015} \\
\hline & \multicolumn{5}{|c|}{ Vermicompost rate } & \multicolumn{5}{|c|}{ Vermicompost rate } \\
\hline & Control & $\operatorname{Mix} 10 \%$ & Mix $20 \%$ & $\operatorname{Mix} 30 \%$ & Mean(B) & Control & Mix $10 \%$ & Mix $20 \%$ & $\operatorname{Mix} 30 \%$ & $\operatorname{Mean}(B)$ \\
\hline \multicolumn{11}{|c|}{$N \%$} \\
\hline Chemical & $2.16 b c$ & $2.33 a b$ & $2.36 \mathrm{a}$ & $2.45 \mathrm{a}$ & $2.33 \mathrm{~A}$ & $2.29 \mathrm{~b}$ & $2.47 \mathrm{a}$ & $2.50 \mathrm{a}$ & $2.60 \mathrm{a}$ & $2.47 \mathrm{~A}$ \\
\hline Vermi-liquid & $1.96 \mathrm{C}$ & $1.98 \mathrm{C}$ & $2.09 b c$ & $2.31 \mathrm{ab}$ & 2.098 & $2.08 \mathrm{C}$ & $2.10 \mathrm{C}$ & $2.22 b$ & $2.45 \mathrm{a}$ & $2.21 \mathrm{~B}$ \\
\hline Vermi-chemical & $2.06 \mathrm{bc}$ & $2.19 b$ & $2.25 b$ & $2.36 \mathrm{a}$ & $2.22 \mathrm{~A}$ & $2.18 \mathrm{bc}$ & $2.32 \mathrm{~b}$ & $2.39 a b$ & $2.51 \mathrm{a}$ & $2.35 \mathrm{~A}$ \\
\hline Mean $(A)$ & $2.06 \mathrm{C}$ & $2.17 \mathrm{~B}$ & $2.23 \mathrm{~B}$ & $2.38 \mathrm{~A}$ & & $2.18 \mathrm{C}$ & $2.30 \mathrm{~B}$ & 2.378 & $2.52 \mathrm{~A}$ & \\
\hline \multicolumn{11}{|c|}{$\mathrm{P} \%$} \\
\hline Chemical & $0.22 \mathrm{de}$ & $0.42 b$ & $0.52 \mathrm{a}$ & $0.53 \mathrm{a}$ & $0.43 \mathrm{~A}$ & $0.24 \mathrm{de}$ & $0.45 b$ & $0.55 a$ & $0.56 \mathrm{a}$ & $0.45 \mathrm{~A}$ \\
\hline Vermi-liquid & $0.24 \mathrm{~d}$ & $0.27 \mathrm{e}$ & $0.32 d$ & $0.43 b$ & 0.328 & $0.26 d$ & $0.28 \mathrm{e}$ & $0.34 d$ & $0.46 b$ & $0.33 \mathrm{~B}$ \\
\hline Vermi-chemical & $0.20 \mathrm{e}$ & $0.39 \mathrm{bc}$ & $0.37 \mathrm{c}$ & $0.42 b$ & 0.348 & $0.22 \mathrm{e}$ & $0.41 b c$ & $0.39 c$ & $0.44 b$ & $0.36 \mathrm{~B}$ \\
\hline $\operatorname{Mean}(\mathrm{A})$ & 0.220 & $0.36 \mathrm{C}$ & $0.40 \mathrm{~B}$ & $0.46 \mathrm{~A}$ & & $0.24 D$ & $0.38 \mathrm{C}$ & $0.43 \mathrm{~B}$ & $0.49 \mathrm{~A}$ & \\
\hline \multicolumn{11}{|c|}{$\mathrm{k} \%$} \\
\hline Chemical & $2.37 b$ & $2.46 \mathrm{a}$ & $2.51 \mathrm{a}$ & $2.66 \mathrm{a}$ & $2.48 \mathrm{~A}$ & $2.51 b$ & $2.61 \mathrm{a}$ & $2.66 \mathrm{a}$ & $2.75 \mathrm{a}$ & $2.63 \mathrm{~A}$ \\
\hline Vermi-liquid & $1.45 \mathrm{ab}$ & $2.11 \mathrm{C}$ & $2.29 \mathrm{de}$ & $2.36 b$ & $2.05 \mathrm{~B}$ & $1.54 \mathrm{ab}$ & $2.23 \mathrm{C}$ & $2.42 \mathrm{de}$ & $2.51 \mathrm{~b}$ & 2.178 \\
\hline Vermi-chemical & $2.15 \mathrm{c}$ & $2.33 b$ & $2.39 a b$ & $2.48 \mathrm{a}$ & $2.34 \mathrm{~A}$ & $2.28 \mathrm{c}$ & $2.47 \mathrm{~b}$ & $2.53 a b$ & $2.63 \mathrm{a}$ & $2.48 \mathrm{~A}$ \\
\hline $\operatorname{Mean}(\mathrm{A})$ & 1.990 & $2.30 \mathrm{C}$ & $2.39 \mathrm{~B}$ & $2.48 \mathrm{~A}$ & & 2.110 & $2.44 \mathrm{C}$ & 2.548 & $2.63 \mathrm{~A}$ & \\
\hline
\end{tabular}


Shaaban, et al

Table 7: The effect of different sources of nutrient solution and Vermicompost rate on the heavy metals of tomato fruits

\begin{tabular}{|c|c|c|c|c|c|c|c|c|c|c|}
\hline \multirow[t]{2}{*}{ Treatments } & \multicolumn{5}{|c|}{ First season 2014} & \multicolumn{5}{|c|}{ Second season 2015} \\
\hline & \multicolumn{5}{|c|}{ Vermicompost rate } & \multicolumn{5}{|c|}{ Vermicompost rate } \\
\hline Nutrient solution & Control & $\operatorname{Mix} 10 \%$ & $\operatorname{Mix} 20 \%$ & Mix $30 \%$ & $\operatorname{Mean}(\mathbf{B})$ & Control & $\operatorname{Mix} 10 \%$ & Mix $20 \%$ & Mix $30 \%$ & Mean(B) \\
\hline \multicolumn{11}{|c|}{$\mathrm{pb} \mathrm{ppm}$} \\
\hline Chemical & 0.00 & 0.00 & 0.00 & 0.00 & 0.00 & 0.00 & 0.00 & 0.00 & 0.00 & 0.00 \\
\hline Vermi-liquid & 0.00 & 0.00 & 0.00 & 0.00 & 0.00 & 0.00 & 0.00 & 0.00 & 0.00 & 0.00 \\
\hline Vermi-chernical & 0.00 & 0.00 & 0.00 & 0.00 & 0.00 & 0.00 & 0.00 & 0.00 & 0.00 & 0.00 \\
\hline Mean $(A)$ & 0.00 & 0.00 & 0.00 & 0.00 & & 0.00 & 0.00 & 0.00 & 0.00 & \\
\hline \multicolumn{11}{|c|}{ Cd ppm } \\
\hline Chemical & 0.00 & 0.00 & 0.00 & 0.00 & 0.00 & 0.00 & 0.00 & 0.00 & 0.00 & 0.00 \\
\hline Vermi-liquid & 0.00 & 0.00 & 0.00 & 0.00 & 0.00 & 0.00 & 0.00 & 0.00 & 0.00 & 0.00 \\
\hline Vermi-chemical & 0.00 & 0.00 & 0.00 & 0.00 & 0.00 & 0.00 & 0.00 & 0.00 & 0.00 & 0.00 \\
\hline $\operatorname{Mean}(\mathrm{A})$ & 0.00 & 0.00 & 0.00 & 0.00 & & 0.00 & 0.00 & 0.00 & 0.00 & \\
\hline \multicolumn{11}{|c|}{ Ni ppm } \\
\hline Chemical & $0.08 \mathrm{a}$ & $0.05 b$ & $0.04 b c$ & $0.03 b c$ & $0.05 \mathrm{~A}$ & $0.09 \mathrm{a}$ & $0.06 \mathrm{~b}$ & $0.05 b c$ & $0.04 b c$ & $0.06 \mathrm{~A}$ \\
\hline Vermi-liquid & $0.01 \mathrm{e}$ & $0.02 \mathrm{~d}$ & $0.02 \mathrm{~d}$ & $0.01 \mathrm{e}$ & $0.01 \mathrm{C}$ & $0.02 \mathrm{e}$ & $0.03 d$ & $0.03 \mathrm{~d}$ & $0.02 \mathrm{e}$ & $0.02 C$ \\
\hline Vermi-chemical & $0.03 \mathrm{~cd}$ & $0.04 c$ & $0.03 c d$ & $0.02 \mathrm{~d}$ & $0.03 \mathrm{~B}$ & $0.04 \mathrm{~cd}$ & $0.05 c$ & $0.04 \mathrm{~cd}$ & $0.03 \mathrm{~d}$ & $0.04 \mathrm{~B}$ \\
\hline Mean (A) & $0.04 \mathrm{~A}$ & $0.04 \mathrm{~A}$ & $0.03 \mathrm{~B}$ & $0.02 C$ & & $0.05 \mathrm{~A}$ & $0.05 \mathrm{~A}$ & $0.04 \mathrm{~B}$ & $0.03 \mathrm{C}$ & \\
\hline \multicolumn{11}{|c|}{ Co ppm } \\
\hline Chemical & $0.31 \mathrm{a}$ & $0.32 \mathrm{a}$ & $0.29 b$ & $0.02 \mathrm{e}$ & $0.24 \mathrm{~A}$ & $0.33 \mathrm{a}$ & $0.34 \mathrm{a}$ & $0.31 \mathrm{ab}$ & $0.03 \mathrm{e}$ & $0.25 \mathrm{~A}$ \\
\hline Vermi-liquid & $0.23 b c$ & $0.15 \mathrm{~d}$ & $0.00 \mathrm{e}$ & $0.00 \mathrm{e}$ & $0.10 \mathrm{C}$ & $0.25 \mathrm{bc}$ & $0.16 d$ & $0.00 \mathrm{e}$ & $0.00 \mathrm{e}$ & $0.11 \mathrm{C}$ \\
\hline Vermi-chemical & $0.27 b c$ & $0.22 \mathrm{~cd}$ & $0.23 b c$ & $0.00 \mathrm{e}$ & $0.18 \mathrm{~B}$ & $0.29 b c$ & $0.23 \mathrm{~cd}$ & $0.24 b c$ & $0,00 \mathrm{e}$ & $0.19 \mathrm{~B}$ \\
\hline Mean (A) & $0.27 \mathrm{~A}$ & $0.23 \mathrm{~B}$ & $0.17 \mathrm{C}$ & 0.010 & & $0.29 \mathrm{~A}$ & $0.24 \mathrm{~B}$ & $0.18 \mathrm{c}$ & $0.02 \mathrm{D}$ & \\
\hline
\end{tabular}

Table : The effect of different sources of nutrient solution and Vermicompost tate on vegetative and vield characteristics of strawberry

\begin{tabular}{|c|c|c|c|c|c|c|c|c|c|c|}
\hline \multirow[t]{2}{*}{ Treatments } & \multicolumn{5}{|c|}{ Second season $(2014 / 2015)$} & \multicolumn{5}{|c|}{ Second season $(2014 / 2015)$} \\
\hline & \multicolumn{5}{|c|}{ Vermicompost rate } & \multicolumn{5}{|c|}{ Vermicompost rate } \\
\hline Nutrient solution & Control & Mix $10 \%$ & Mix 20\% & Mix $30 \%$ & Mean(B) & Contral & Mix $10 \%$ & Mix $20 \%$ & $\operatorname{Mix} 30 \%$ & Mean $(B)$ \\
\hline \multicolumn{11}{|c|}{ Number of leaves } \\
\hline Chemical & $18.63 \mathrm{de}$ & $20.43 \mathrm{~cd}$ & $22.33 \mathrm{abc}$ & $24.93 a$ & $21.85 \mathrm{~A}$ & $19.74 \mathrm{de}$ & $21.66 \mathrm{~cd}$ & $23.67 \mathrm{abc}$ & $26.42 \mathrm{a}$ & $23.16 \mathrm{~A}$ \\
\hline Vermi-liquid & $17.70 \mathrm{e}$ & $20.86 \mathrm{~cd}$ & $23.53 \mathrm{ab}$ & $24.33 \mathrm{ab}$ & $21.60 \mathrm{~A}$ & $18.76 \mathrm{e}$ & $22.11 \mathrm{~cd}$ & $24.94 \mathrm{ab}$ & $25.78 \mathrm{ab}$ & $22.89 \mathrm{~A}$ \\
\hline Vermi-chemical & 18.83 de & $19.93 \mathrm{cde}$ & $21.86 b c$ & $24.30 \mathrm{ab}$ & $21.23 \mathrm{~A}$ & $19.95 \mathrm{de}$ & 21.13 cde & $23.17 b c$ & $25.75 a b$ & $22.50 \mathrm{~A}$ \\
\hline $\operatorname{Mean}(A)$ & $18.39 \mathrm{D}$ & $20.41 \mathrm{C}$ & $22.58 \mathrm{~B}$ & $24.52 \mathrm{~A}$ & & $19.49 \mathrm{D}$ & 33 & $23.93 \mathrm{~B}$ & $25.99 \mathrm{~A}$ & \\
\hline \multicolumn{11}{|c|}{ leave area $\mathrm{cm}^{2}$} \\
\hline Chemical & $13.60 \mathrm{bcd}$ & $14.56 \mathrm{abc}$ & $15.96 \mathrm{abc}$ & $18.76 \mathrm{a}$ & $14.52 \mathrm{~A}$ & 14.41 bcd & $15.43 \mathrm{abc}$ & $16.91 \mathrm{abc}$ & $19.88 \mathrm{a}$ & $15.39 \mathrm{~A}$ \\
\hline Vermi-liquid & $8.51 \mathrm{e}$ & 10.00 de & $13.15 \mathrm{~cd}$ & $17.70 \mathrm{ab}$ & $12.34 \mathrm{~A}$ & $9.02 \mathrm{e}$ & $10.60 \mathrm{de}$ & $13.93 \mathrm{~cd}$ & $18.76 \mathrm{ab}$ & $13.07 \mathrm{~A}$ \\
\hline Vermi-chemical & $9.75 \mathrm{ed}$ & $12.55 \mathrm{cde}$ & $15.96 \mathrm{abc}$ & $18.45 \mathrm{a}$ & $14.17 \mathrm{~A}$ & $10.33 \mathrm{ed}$ & $13.3 \mathrm{cde}$ & $16.91 \mathrm{abc}$ & $19.55 \mathrm{a}$ & $15.02 \mathrm{~A}$ \\
\hline $\operatorname{Mean}(A)$ & $10.62 \mathrm{C}$ & $12.37 \mathrm{~B}$ & $15.02 \mathrm{~B}$ & $18.30 \mathrm{~A}$ & & $11.25 \mathrm{C}$ & $1 \mathrm{~B}$ & 15.928 & $19.39 \mathrm{~A}$ & \\
\hline \multicolumn{11}{|c|}{ Number of fruits /plant } \\
\hline Chemical & $18.56 \mathrm{a}$ & & & $22.33 a$ & $21.02 \mathrm{~A}$ & $19.67 \mathrm{a}$ & $22.75 \mathrm{a}$ & $23.06 \mathrm{a}$ & $23.66 \mathrm{a}$ & $22.28 \mathrm{~A}$ \\
\hline Vermi-liquid & $17.33 \mathrm{a}$ & $18.13 \mathrm{a}$ & $19.10 \mathrm{a}$ & $19.43 \mathrm{a}$ & $18.49 \mathrm{~A}$ & $18.36 a$ & $19.21 \mathrm{a}$ & $20.25 \mathrm{a}$ & $20.60 \mathrm{a}$ & $19.60 \mathrm{~A}$ \\
\hline Vermi-chemical & $17.76 \mathrm{a}$ & $18.10 \mathrm{a}$ & $19.66 \mathrm{a}$ & $20.76 a$ & $19.07 \mathrm{~A}$ & $18.82 \mathrm{a}$ & $19.18 \mathrm{a}$ & $20.83 a$ & $22.00 \mathrm{a}$ & $20.20 \mathrm{~A}$ \\
\hline $\operatorname{Mean}(A)$ & $17.89 \mathrm{~A}$ & $19.23 \mathrm{~A}$ & $20.17 \mathrm{~A}$ & $20.84 \mathrm{~A}$ & & $18.96 \mathrm{~A}$ & $20.38 \mathrm{~A}$ & $21.38 \mathrm{~A}$ & $22.09 \mathrm{~A}$ & \\
\hline \multicolumn{11}{|c|}{ Total yield g/plant } \\
\hline Chemical & $344.67 d$ & $373.33 c$ & $466.00 \mathrm{~b}$ & $545.67 \mathrm{a}$ & $432.41 \mathrm{~A}$ & $365.35 \mathrm{~d}$ & $395.72 \mathrm{c}$ & $493.96 \mathrm{~b}$ & $578.41 \mathrm{a}$ & $458.36 \mathrm{~A}$ \\
\hline Vermi-liquid & $340.67 d$ & $348.33 \mathrm{~cd}$ & $451.00 \mathrm{~b}$ & $553.33 \mathrm{a}$ & $423.33 \mathrm{~A}$ & $361.11 \mathrm{~d}$ & $369.22 \mathrm{~cd}$ & $478.06 \mathrm{~b}$ & $586.53 \mathrm{a}$ & $448.73 \mathrm{~A}$ \\
\hline Vermi-chemical & $354.00 \mathrm{~cd}$ & $359.67 \mathrm{~cd}$ & $450.67 \mathrm{~b}$ & $555.00 \mathrm{a}$ & $429.83 \mathrm{~A}$ & $375.24 \mathrm{~cd}$ & $381.25 \mathrm{~cd}$ & $477.71 \mathrm{~b}$ & $588.30 \mathrm{a}$ & $455.62 \mathrm{~A}$ \\
\hline $\operatorname{Mean}(A)$ & $346.45 \mathrm{C}$ & $360.44 \mathrm{C}$ & $455.89 \mathrm{~B}$ & $551.33 \mathrm{~A}$ & & $367.23 \mathrm{C}$ & $382.06 \mathrm{C}$ & $483.24 \mathrm{~B}$ & $584.40 \mathrm{~A}$ & \\
\hline
\end{tabular}


J. Environ. Sci.

Institute of Environmental Studies and Research - Ain Shams University

Table 9: The effect of different sources of nutrient solution and Vermicompost rate on chemical quality properties of strawberry

\begin{tabular}{|c|c|c|c|c|c|c|c|c|c|c|}
\hline \multirow{3}{*}{$\begin{array}{l}\text { Treatments } \\
\text { lutrient solution }\end{array}$} & \multicolumn{5}{|c|}{ First season( 2013/2014) } & \multicolumn{5}{|c|}{ Second season( 2014/2015) } \\
\hline & \multicolumn{5}{|c|}{ Vermicompost rate } & \multicolumn{5}{|c|}{ Vermicompost rate } \\
\hline & Control & $\mathrm{Mix} 10 \%$ & Mix $20 \%$ & Mix $30 \%$ & Mean(8) & Control & Mix $10 \%$ & $\operatorname{Mix} 20 \%$ & $\operatorname{Mix} 30 \%$ & Mean(g) \\
\hline \multicolumn{11}{|c|}{ T.S.S $(\%)$} \\
\hline Chemical & $6.90 \mathrm{bc}$ & $8.20 b c$ & $6.97 \mathrm{bc}$ & 9.97 ab & $8.01 \mathrm{~A}$ & $7.31 \mathrm{bc}$ & $8.69 b c$ & $7.38 \mathrm{bc}$ & $10.56 \mathrm{ab}$ & $8.49 \mathrm{~A}$ \\
\hline Vermi-liquid & $6.20 \mathrm{c}$ & $6.87 \mathrm{bc}$ & $6.83 b c$ & $9.93 \mathrm{ab}$ & $7.46 \mathrm{~B}$ & $6.57 \mathrm{c}$ & $7.28 b c$ & $7.24 b c$ & 10.53 ab & 7.918 \\
\hline Vermi-chemical & $7.00 \mathrm{bc}$ & $9.55 \mathrm{ab}$ & $8.40 b c$ & $11.62 \mathrm{a}$ & $9.14 \mathrm{~A}$ & $7.42 \mathrm{bc}$ & $10.12 \mathrm{ab}$ & $8.90 \mathrm{bc}$ & $12.31 \mathrm{a}$ & $9.69 \mathrm{~A}$ \\
\hline $\operatorname{Mean}(A)$ & $6.70 \mathrm{C}$ & $8.21 \mathrm{~B}$ & $7.40 B C$ & $10.51 \mathrm{~A}$ & & $7.10 \mathrm{C}$ & $8.70 \mathrm{~B}$ & $7.84 \mathrm{BC}$ & $11.14 \mathrm{~A}$ & \\
\hline \multicolumn{11}{|c|}{ Total chlorophyll content (Spad) } \\
\hline Chemical & $45.49 d$ & $46.19 d$ & $47.77 b c$ & $57.48 \mathrm{~b}$ & $49.23 \mathrm{~A}$ & $48.22 \mathrm{~d}$ & $48.96 \mathrm{~d}$ & $50.64 \mathrm{bc}$ & $60.93 b$ & $52.18 \mathrm{~A}$ \\
\hline Vermi-liquid & $43.12 \mathrm{e}$ & $45.08 \mathrm{~d}$ & 49.36 bc & $58.53 \mathrm{~b}$ & $49.02 \mathrm{~A}$ & $45.71 \mathrm{e}$ & $47.78 \mathrm{~d}$ & $52.32 \mathrm{bc}$ & $62.04 b$ & $52.43 \mathrm{~A}$ \\
\hline Vermi-chemical & $44.80 \mathrm{~d}$ & $46.69 \mathrm{~d}$ & 49.97 bc & $60.29 \mathrm{a}$ & $50.44 \mathrm{~A}$ & $47.49 \mathrm{~d}$ & $49.49 \mathrm{~d}$ & $52.96 \mathrm{bc}$ & $63.91 \mathrm{a}$ & $53.46 \mathrm{~A}$ \\
\hline $\operatorname{Mean}(A)$ & $44.47 \mathrm{~B}$ & $45.99 \mathrm{~B}$ & $49.03 \mathrm{~B}$ & $58.77 \mathrm{~A}$ & & $47.14 \mathrm{~B}$ & $48.74 \mathrm{~B}$ & $51.92 \mathrm{~B}$ & $62.29 \mathrm{~A}$ & \\
\hline \multicolumn{11}{|c|}{ Acidity $(\%)$} \\
\hline Chemical & $0.07 \mathrm{~b}$ & $0.04 b$ & $0.06 \mathrm{~b}$ & $0.15 \mathrm{a}$ & $0.08 \mathrm{~A}$ & $0.08 \mathrm{~b}$ & $0.05 b$ & $0.07 b$ & $0.16 a$ & $0.09 \mathrm{~A}$ \\
\hline Vermi-liquid & $0.01 \mathrm{~d}$ & $0.03 c$ & $0.02 \mathrm{C}$ & $0.03 c$ & $0.02 \mathrm{C}$ & $0.02 \mathrm{~d}$ & $0.04 \mathrm{C}$ & $0.03 c$ & $0.04 \mathrm{C}$ & $0.03 C$ \\
\hline Vermi-chemical & $0.02 \mathrm{c}$ & $0.05 b$ & $0.05 \mathrm{~b}$ & $0.06 \mathrm{~b}$ & $0.05 B$ & $0.03 \mathrm{C}$ & $0.06 b$ & $0.06 b$ & $0.07 \mathrm{~b}$ & 0.068 \\
\hline $\operatorname{Mean}(A)$ & $0.03 \mathrm{~B}$ & 0.048 & 0.048 & $0.08 \mathrm{~A}$ & & 0.048 & $0.05 \mathrm{~B}$ & $0.05 B$ & $0.09 \mathrm{~A}$ & \\
\hline \multicolumn{11}{|c|}{ Vitamin C (mg/100gfiw) } \\
\hline Chemical & $53.44 \mathrm{C}$ & $60.58 \mathrm{bc}$ & $73.53 \mathrm{ab}$ & $81.70 \mathrm{a}$ & $67.31 \mathrm{~A}$ & $56.65 \mathrm{c}$ & $64.21 \mathrm{bc}$ & $77.94 a b$ & $86.60 \mathrm{a}$ & $71.35 \mathrm{~A}$ \\
\hline Vermi-liquid & $50.00 \mathrm{c}$ & $62.46 \mathrm{bc}$ & $63.47 \mathrm{bc}$ & $83.63 \mathrm{a}$ & $64.89 \mathrm{~A}$ & $53.00 \mathrm{c}$ & $66.21 \mathrm{bc}$ & $67.28 \mathrm{bc}$ & $88.65 \mathrm{a}$ & $68.79 \mathrm{~A}$ \\
\hline Vermi-chemical & $53.73 \mathrm{C}$ & $58.80 \mathrm{bc}$ & $73.38 \mathrm{ab}$ & $85.52 a$ & $67.86 \mathrm{~A}$ & $56.95 \mathrm{c}$ & $62.33 b c$ & $77.78 \mathrm{ab}$ & $90.65 a$ & $71.93 \mathrm{~A}$ \\
\hline $\operatorname{Mean}(A)$ & $52.39 \mathrm{D}$ & $60.61 \mathrm{C}$ & $70.13 \mathrm{~B}$ & $83.62 \mathrm{~A}$ & & $55.53 \mathrm{D}$ & $64.24 \mathrm{C}$ & $74.34 \mathrm{~B}$ & $88.64 \mathrm{~A}$ & \\
\hline
\end{tabular}

Table 10: The effect of different sources of nutrient solution and Vermicompost rate on $N, P$ and $K \%$ of strawberry leaves.

\begin{tabular}{|c|c|c|c|c|c|c|c|c|c|c|}
\hline \multirow[t]{2}{*}{ Treatments } & \multicolumn{5}{|c|}{ First season(2013/2014) } & \multicolumn{5}{|c|}{ First season( 2013/2014) } \\
\hline & \multicolumn{5}{|c|}{ Vermicompost rate } & \multicolumn{5}{|c|}{ Vermicompost rate } \\
\hline Nutrient solution & Control & Mix $10 \%$ & Mix $20 \%$ & $\operatorname{Mix} 30 \%$ & $\operatorname{Mean}(\bar{\theta})$ & Control & Mix $10 \%$ & Mix $20 \%$ & Mix $30 \%$ & Mean(B) \\
\hline \multicolumn{11}{|c|}{ N $\%$} \\
\hline Chemical & $2.00 \mathrm{~b}$ & $2.00 \mathrm{~b}$ & $2.21 b$ & $2.30 \mathrm{a}$ & $2.13 \mathrm{~A}$ & $2.12 b$ & $2.12 b$ & $2.35 b$ & $2.44 \mathrm{a}$ & $2.26 \mathrm{~A}$ \\
\hline Vermi-liquid & $1.18 \mathrm{e}$ & $1.68 d$ & $1.85 \mathrm{~cd}$ & $2.05 b$ & $1.69 \mathrm{C}$ & $1.12 \mathrm{e}$ & $1.78 \mathrm{~d}$ & $1.96 \mathrm{~cd}$ & $2.17 b$ & $1.76 \mathrm{C}$ \\
\hline Vermi-chemical & $1.75 \mathrm{~d}$ & $1.89 \mathrm{c}$ & $2.05 b$ & $2.21 b$ & $1.98 \mathrm{~B}$ & $1.86 \mathrm{~d}$ & $2.00 \mathrm{c}$ & $2.17 b$ & $2.34 b$ & $2.09 \mathrm{~B}$ \\
\hline Mean (A) & 1.640 & $1.86 \mathrm{C}$ & $2.04 \mathrm{~B}$ & $2.19 \mathrm{~A}$ & & 1.700 & $1.97 \mathrm{C}$ & $2.16 \mathrm{~B}$ & $2.32 \mathrm{~A}$ & \\
\hline \multicolumn{11}{|c|}{$P \%$} \\
\hline Chemical & $0.43 \mathrm{~cd}$ & $0.53 \mathrm{ab}$ & $0.60 \mathrm{a}$ & $0.60 \mathrm{a}$ & $0.54 \mathrm{~A}$ & $0.45 \mathrm{~cd}$ & $0.57 \mathrm{ab}$ & $0.63 \mathrm{a}$ & $0.64 \mathrm{a}$ & $0.57 \mathrm{~A}$ \\
\hline Vermi-liquid & $0.16 f$ & $0.19 \mathrm{f}$ & $0.18 \mathrm{f}$ & $0.24 f$ & $0.19 \mathrm{C}$ & $0.17 f$ & $0.20 f$ & $0.19 \mathrm{f}$ & $0.25 f$ & $0.20 \mathrm{C}$ \\
\hline Vermi-chemical & $0.33 \mathrm{e}$ & $0.33 \mathrm{e}$ & $0.37 \mathrm{de}$ & $0.48 \mathrm{bc}$ & $0.38 \mathrm{~B}$ & $0.35 \mathrm{e}$ & $0.35 \mathrm{e}$ & $0.40 \mathrm{de}$ & $0.51 b c$ & $0.40 \mathrm{~B}$ \\
\hline Mean (A) & 0.310 & $0.35 \mathrm{C}$ & $0.38 \mathrm{~B}$ & $0.44 \mathrm{~A}$ & & $0.32 \mathrm{D}$ & $0.37 \mathrm{C}$ & $0.41 \mathrm{~B}$ & $0.46 \mathrm{~A}$ & \\
\hline \multicolumn{11}{|c|}{$k \%$} \\
\hline Chemical & $2.45 \mathrm{a}$ & $2.44 a$ & $2.39 \mathrm{a}$ & $2.55 \mathrm{a}$ & $2.46 \mathrm{~A}$ & $2.60 \mathrm{a}$ & $2.58 \mathrm{a}$ & $2.54 a$ & $2.70 \mathrm{a}$ & $2.60 \mathrm{~A}$ \\
\hline Vermi-liquid & $1.01 \mathrm{e}$ & $1.44 d$ & $1.82 \mathrm{C}$ & $1.99 \mathrm{bc}$ & $1.57 \mathrm{C}$ & $1.08 \mathrm{e}$ & $1.53 \mathrm{~d}$ & $1.93 \mathrm{C}$ & $2.11 b c$ & $1.66 \mathrm{C}$ \\
\hline Vermi-chemical & $2.26 \mathrm{ab}$ & $2.24 \mathrm{ab}$ & $2.24 a b$ & $2.24 \mathrm{ab}$ & $2.24 \mathrm{~B}$ & $2.39 \mathrm{ab}$ & $2.37 \mathrm{ab}$ & $2.37 \mathrm{ab}$ & $2.38 \mathrm{ab}$ & $2.38 \mathrm{~B}$ \\
\hline $\operatorname{Mean}(A)$ & 1.910 & $2.04 \mathrm{C}$ & $2.15 B$ & $2.26 \mathrm{~A}$ & & $2.02 \mathrm{D}$ & $2.16 \mathrm{C}$ & $2.28 \mathrm{~B}$ & $2.40 \mathrm{~A}$ & \\
\hline
\end{tabular}


Table 11: The effect of different sources of nutrient solution and Vermicompost rate on heavy metals concentration of strawbern fruits

\begin{tabular}{|c|c|c|c|c|c|c|c|c|c|c|}
\hline \multirow[t]{2}{*}{ Treatments } & \multicolumn{5}{|c|}{ First season $(2013 / 2014)$} & \multicolumn{5}{|c|}{ First season (2013/2014) } \\
\hline & \multicolumn{5}{|c|}{ Vermicompost rate } & \multicolumn{5}{|c|}{ Vermicompost rate } \\
\hline Nutrient solution & Control & Mix $10 \%$ & Mix $20 \%$ & Mix $30 \%$ & Mean(B) & Contro! & $\operatorname{Mix} 10 \%$ & Mix $20 \%$ & Mix 30\% & Mean(8) \\
\hline \multicolumn{11}{|c|}{ Po ppm } \\
\hline Chemical & 0.00 & 0.00 & 0.00 & 0.00 & 0.00 & 0.00 & 0.00 & 0.00 & 0.00 & 0.00 \\
\hline Vermi-liquid & 0.00 & 0.00 & 0.00 & 0.00 & 0.00 & 0.00 & 0.00 & 0.00 & 0.00 & 0.00 \\
\hline Vermi-chemical & 0.00 & 0.00 & 0.00 & 0.00 & 0.00 & 0.00 & 0.00 & 0.00 & 0.00 & 0.00 \\
\hline Mean (A) & 0.00 & 0.00 & 0.00 & 0.00 & & 0.00 & 0.00 & 0.00 & 0.00 & \\
\hline \multicolumn{11}{|c|}{ Cd ppm } \\
\hline Chemical & $1.18 \mathrm{a}$ & $0.77 \mathrm{c}$ & $0.88 \mathrm{~b}$ & $1.08 \mathrm{a}$ & $0.98 \mathrm{~A}$ & $1.25 \mathrm{a}$ & $0.81 c$ & $0.93 \mathrm{~b}$ & $1.14 \mathrm{a}$ & $1.03 \mathrm{~A}$ \\
\hline Vermi-liquid & $0.34 \mathrm{e}$ & $0.34 \mathrm{e}$ & $0.56 \mathrm{~d}$ & $0.23 f$ & $0.37 \mathrm{C}$ & $0.36 \mathrm{e}$ & $0.36 \mathrm{e}$ & $0.59 \mathrm{~d}$ & $0.24 f$ & $0.39 \mathrm{C}$ \\
\hline Vermi-chemical & $0.74 \mathrm{c}$ & $0.83 c$ & $0.85 \mathrm{c}$ & $0.96 \mathrm{~b}$ & $0.84 \mathrm{~B}$ & $0.78 \mathrm{c}$ & $0.87 \mathrm{C}$ & $0.90 \mathrm{c}$ & $1.01 b$ & $0.89 \mathrm{~B}$ \\
\hline $\operatorname{Mean}(A)$ & $0.75 \mathrm{~A}$ & $0.65 \mathrm{~B}$ & $0.76 \mathrm{~A}$ & $0.76 \mathrm{~A}$ & & $0.79 \mathrm{~B}$ & $0.68 \mathrm{~B}$ & $0.80 \mathrm{~A}$ & $0.80 \mathrm{~A}$ & \\
\hline \multicolumn{11}{|c|}{ NI ppm } \\
\hline Chemical & $0.11 \mathrm{a}$ & $0.07 b c$ & $0.08 \mathrm{~b}$ & $0.07 b c$ & $0.08 \mathrm{~A}$ & $0.12 \mathrm{a}$ & $0.08 b c$ & $0.09 \mathrm{~b}$ & $0.08 b c$ & $0.09 \mathrm{~A}$ \\
\hline Vermi-liquid & $0.05 d$ & $0.05 d$ & $0.06 \mathrm{~cd}$ & $0.04 \mathrm{e}$ & $0.05 \mathrm{C}$ & $0.06 \mathrm{~d}$ & $0.06 \mathrm{~d}$ & $0.07 \mathrm{~cd}$ & $0.05 \mathrm{e}$ & $0.06 \mathrm{C}$ \\
\hline Vermi-chemical & $0.06 \mathrm{~cd}$ & $0.06 \mathrm{~cd}$ & $0.07 \mathrm{c}$ & $0.09 b$ & $0.07 \mathrm{~B}$ & $0.07 \mathrm{~cd}$ & $0.07 \mathrm{~cd}$ & $0.08 \mathrm{c}$ & $0.10 \mathrm{~b}$ & $0.08 \mathrm{~B}$ \\
\hline $\operatorname{Mean}(A)$ & $0.07 \mathrm{~A}$ & $0.06 \mathrm{C}$ & $0.07 \mathrm{~A}$ & $0.07 \mathrm{~A}$ & & $0.08 \mathrm{C}$ & $0.07 \mathrm{C}$ & $0.08 \mathrm{~B}$ & $0.08 \mathrm{~A}$ & \\
\hline \multicolumn{11}{|c|}{ Co ppm } \\
\hline Chemical & $0.15 a$ & $0.09 b c$ & $0.06 \mathrm{~cd}$ & $0.14 a b$ & $0.11 \mathrm{~A}$ & $0.16 \mathrm{a}$ & $0.10 \mathrm{bc}$ & $0.07 \mathrm{~cd}$ & $0.15 \mathrm{ab}$ & $0.12 \mathrm{~A}$ \\
\hline Vermi-liquid & $0.00 \mathrm{e}$ & $0.01 \mathrm{e}$ & $0.03 \mathrm{de}$ & $0.00 \mathrm{e}$ & $0.01 \mathrm{C}$ & $0.01 \mathrm{e}$ & $0.02 \mathrm{e}$ & $0.04 \mathrm{de}$ & $0.01 \mathrm{e}$ & $0.02 \mathrm{C}$ \\
\hline Vermi-chemical & $0.00 \mathrm{e}$ & $0.05 \mathrm{de}$ & $0.07 \mathrm{~cd}$ & $0.10 b c$ & $0.06 \mathrm{~B}$ & $0.01 \mathrm{e}$ & $0.06 \mathrm{de}$ & $0.08 \mathrm{~cd}$ & $0.11 b c$ & 0.078 \\
\hline $\operatorname{Mean}(A)$ & $0.05 \mathrm{~B}$ & $0.05 \mathrm{~B}$ & $0.05 \mathrm{~B}$ & $0.08 \mathrm{~A}$ & & $0.06 \mathrm{~B}$ & $0.06 \mathrm{~B}$ & $0.06 \mathrm{~B}$ & $0.09 \mathrm{~A}$ & \\
\hline
\end{tabular}

\section{REFERENCES}

Aalok, A; Tripathi A.K. and Soni, P. (2008): Vermicomposting: A Better Option for Organic Solid Waste Management. J. Hum. Ecol. 24, 59-64.

AboSedera,F.A; Shafshak.N.S; Shams,A.S; Abul-Soud, M.A. and Mohammed, M.H.(2015): The utilize of Vermicomposting Outputs in Substrate Culture for Producing Snap Bean. Annals of Agric. Sci., Moshtohor,; 53 (1): 139 -151.

Abul-Soud,M.(2015): Achieve food security of some leafy vegetables in urban (How to create resilience cities?). Global Journal of Advanced Research, 2,(10): 1705-1722.

Abul-Soud,M; Medany, M; Hassanein, M.K. ; Abul-Matty, S.h. and Abuhadid,A.F. (2009): Case study: Vermiculture and vermicomposting technologies use in sustainable agriculture in Egypt. The seventh international conference of organic agriculture, Cairo, Egypt. Egypt. J. Agric.,2009; 87 (1), 389:403. 
J. Environ. Sci.

Institute of Environmental Studies and Research - Ain Shams University

Abul-Soud, M.A; Emam, M.S.A; Hawash, A.H; Hassan, M; and Yahia, Z. (2015a): The utilize of vermicomposting outputs in ecology soilless culture of lettuce. Journal of Agriculture and Ecology Research, 5(1): 1-15, Article no.JAERI.20008

Abul-Soud, M.A; Emam, M.S.A; and Abd El-Rahman Noha, G. (2015b): The potential use of vermicompost in soilless culture for producing strawberry. International Journal of Plant \& Soil Scienc; 8 (5): 1 15 .

Abul-Soud, M.A; Emam, M.S.A; Abdrabbo, M.A.A. and Hashem, F.A. (2014): Sustainable Urban Horticulture of Sweet Pepper Vermicomposting in Summer Season. J. of Advanced in Agri; 3 )1(: 110-122)

Arancon, N.Q; C.A. Edwards; Bierman P; C. Welch and J.D. Metzger. (2004b): Influences of vermicomposts on field strawberries-1: Effects on growth and yields; Bioresource Technology, 93: 145153.

Arancon, N.Q; Edwards, C.A; Atiyeh, R.M. and Metzger, J.D. (2004a): Effects of vermicomposts produced from food waste on greenhouse peppers. Bioresource Technology, 93: 139-144.

Association of Official Analytical Chemists 1990. Methods of analysis, Washington 44, DC.V.S.A.

Atiyeh, R.M; Lee, S; Edwards, C.A; Arancon, N.Q; Metzger, J.D. (2002): The influence of humic acids derived from earthworm-processed organic wastes on plant growth. Bioresource Technology 84:7-14.

Atiyeh, R. M; Edwards, C. A; Metzger, J. D; Lee, S.and Arancon, N. Q. (2002): The influence of humic acids derived from earthwormprocessed organic wastes on plant growth. Bioresource Technology 84, 7-14.

Buckerfield, J. C; Webster, K. A. (1998): Worm-worked waste boosts grape yields: prospects for vermicompost use in vineyards. Australian and New Zealand Wine Industry Journal 13, 73-76. 
Bvenura, C. and Afolayan ,A.J. (2015): The role of wild vegetables in household food security in South Africa: Areview. / Food Research International 76: 1001-1011.

Chamani, E; Joyce, D.C. and Reihanytabar, A. (2008): Vermicompost effects on the growth and flowering of Petunia hybrid "Dream Neon Rose". American-Eurasian J.Agric.\&Environ.Sci. 3(3):506-512

Chapman, H. D. and P. F. Pratt, (1961): Methods of analysis for soil, plant and water. Calif. Univ., USA.

Datt. N, Y. P. Dubey and C.h. Rohina. (2013): Studies on impact of organic, inorganic and integrated use of nutrients on symbiotic parameters, yield, and quality of French-bean (Phaseolus vulgaris L.) vis-à-vis soil properties of an acid alfisol. African Journal of Agricultural Research, 8(22), pp. 2645-2654.

El Behairy, U.A.(1994): The effect of levels of phosphorus and zinc in the nutrient solution on macro and micronutrients uptake and translocation in cucumber (Cucumus sativus L.) grown by nutrient film technique. Ph.D thesis, London Univeristy p: 299.

FAO( 1980): Soil and Plant Analysis. Soils Bulletin 38/2,250.

FAO(2012): Growing greener cities in Africa. First status report on urban and peri-urban horticulture in Africa. 216. ISBN 978-92-5-107286-8.

Fernández-Luqueño,F; $\quad$ Reyes-Varela,V.;Martínez-Suárez,C.;SalomónHernández, G; Yáñez-Meneses, J; Ceballos-Ramírez, J.M. and Dendooven, L. (2010): Effect of different nitrogen sources on plant characteristics and yield of common bean (Phaseolus vulgaris L.). Biores. Technol., 101: 396-403

Hara, Y; A. Murakami; K. Tsuchiya; A. M. Palijon and M. Yokoharid. A. (2013): Quantitative assessment of vegetable farming on vacant lots in an urban fringe area in Metro Manila: Can it sustain longterm local vegetable demand? Applied Geography, 41 195-206.

Inbar, Y; Hadar, Y. and Chen, Y.(1993): Recycling of cattle manure: the composting process and characterization of maturity. Journal of Environmental Quality 22, 857-863. 
J. Environ. Sci.

Institute of Environmental Studies and Research - Ain Shams University

Lagerkvist, C.J; S. Hess ; J. Okello ; H. Hansson and Nancy Karanja. (2013): Food health risk perceptions among consumers, farmers, and traders of leafy vegetables in Nairobi. Food Policy 38: 92-104.

McBride, M.B; H. A. Shayler; H. M. Spliethoff; R. G. Mitchell; L. G. Marquez-Bravo; G. S. Ferenz; J. M. Russell-Anelli; L. Casey and S. Bachman.(2014): Environmental Pollution 194: 254-261.

Muscolo, A; Bovalo F; Gionfriddo ,F. and Nardi ,F.(1999): Earthworm humic matter produces auxin-like effects on Daucuscarotacell growth and nitrate metabolism. Soil Biol. Biochem., 31:1303-1311.

Nabulo ,G., C.R. Black, J. Craigon, S.D. Young.(2012): Does consumption of leafy vegetables grown in peri-urban agriculture pose a risk to human health? Environmental Pollution 162: 389-398.

Raul, I.C.(1996): Measuring physical properties. Rutgers Cooperative Extension. New Jersey Agriculture Experiment Station. New Jersey University.

Raul, I. C; (1996): Measuring physical properties. Rutgers Cooperative Extension. New Jersey Agriculture Experiment Station. New Jersey university.Rego, L.F.G. (2014). Urban vegetable production for sustainability: The Riortas Project in the city of Rio de Janeiro, Brazil . Habitat International 44 510-516.

Säumel, I; I. Kotsyuk; Marie Hölscher; Claudia Lenkereit; F.and Weber; I. Kowarik.( 2012): How healthy is urban horticulture in high traffic areas? Trace metal concentrations in vegetable crops from plantings within inner city neighborhoods in Berlin, Germany. Environmental Pollution 165: 124-132.

Sharma, S; Dubey, Y.P; Kaistha, B.P; Verma, T.S. (2008): Rhizobium and phosphorus interaction on N-P uptake by French bean (Phaseolus vulgaris,L) in an acid Alfisol from northwest Himalayan region. J. Indian Soc. Soil Sci. 56:118-122.

Snedicor, G.W. and Cochran, W.G.( 1981): "Statistical Methods" 7th ed., Iowa State Univ., Press, Ames, Iowa, USA, 225-330.

Snedicor, G.W.and Cochran, W.G. (1981): Statistical methods. 7th Iowa State Univ. Press, Iowa, USA,;225-320 . 
Watanabe, F.S., and Olsen, S.R.. (1965): Test of an ascorbic acid method for determining phosphorus in water and $\mathrm{NaHCO} 3$ extracts from soils. Soil Sci. Soc. Am. Proc. 29:677-678.

Wertheim-Heck, S.C.O; G. Spaargaren and S. Vellema.( 2014): Food safety in everyday life: Shopping for vegetables in a rural city in Vietnam. Journal of Rural Studies 35: 37-48.

Wilson, D.P.and Carlile, W.R.(1989): Plant growth in potting media containing worm-worked duck waste. Acta Horticulture. 238:205220 .

Wilson, D.P.and Carlile, W.R. (1989): Plant growth in potting media containing worm-worked duck waste. Acta Horticulture. 238:205220 .

Wilson, G.C.S.(1983): The physic- chemical and physical properties of horticultural substrate. Acta Hort 150: 19-32

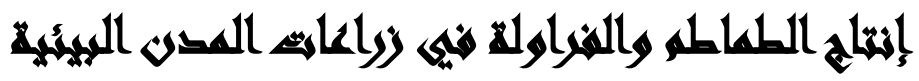

[7]

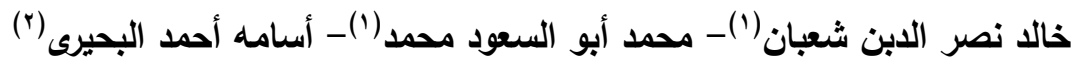

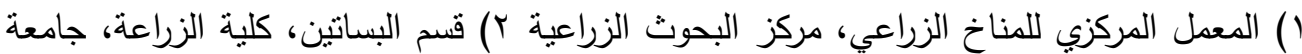

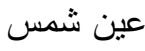

\section{المسترلت}

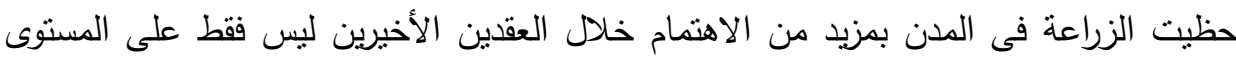

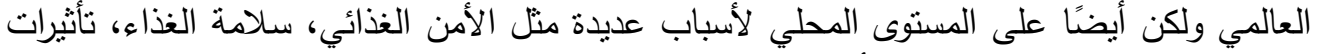

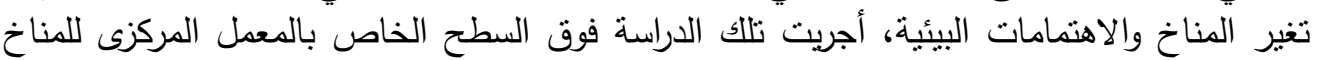

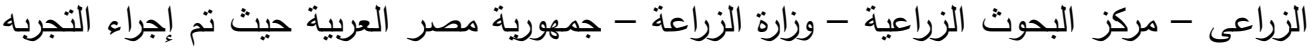

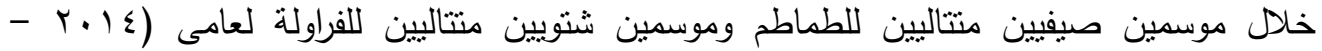

.$(r \cdot 10$

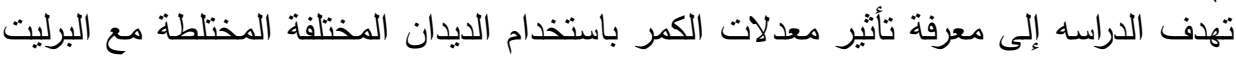

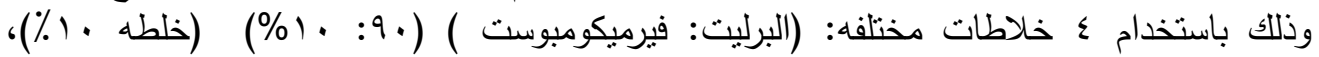

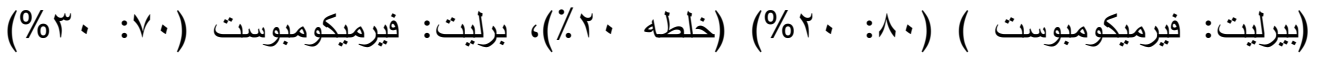

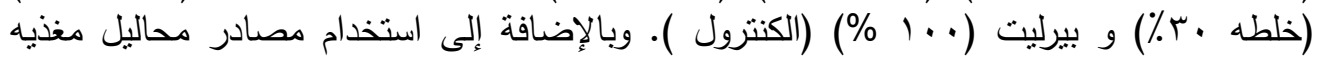


J. Environ. Sci.

Institute of Environmental Studies and Research - Ain Shams University

منل ( محلول كيماوي، فيرميليكويد، ومحلول كيماوى وفيرميلكويد ) علي جودة وإنتاجية الطماطم

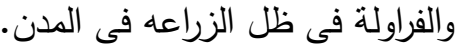

أظهرت النتائج المتحصل عليها أن الخواص الخضرية والئرئ المحصولية وخصائص الجودة الكيميائية

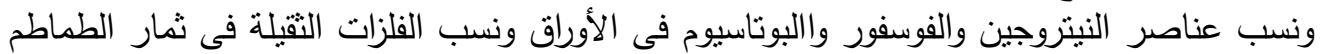

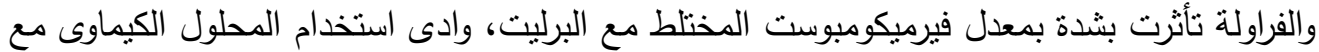

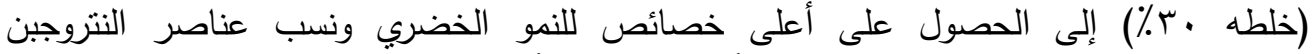

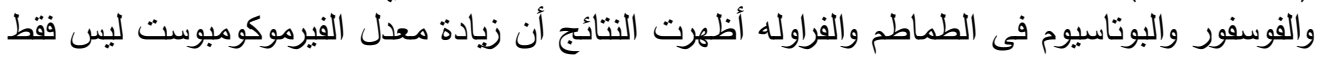

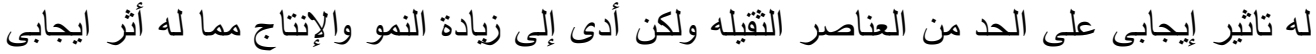

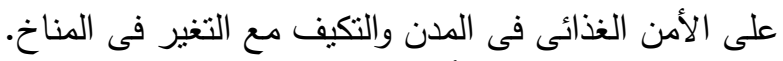

الكلمات الداله: زراعة الأسطح- زراعة المدن - فيرميكومبوست - المحلول المغذى - طماطم- فراوله-

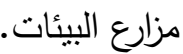

